\title{
Siriah Gadang: Galombang Dance Elements in Reconstruction in Pariangan, West Sumatra
}

\author{
Afifah Asriati, Desfiarni, and Irdhan Epria Darma Putra \\ Universitas Negeri Padang, Padang, Indonesia
}

ORCID:

Afifah Asriati: http://orcid.org/0000-0001-9936-4290

\section{Abstract}

This article aimed to revive the use of Siriah Gadang in the reconstruction of the Galombang dance in Nagari Pariangan, Tanah Datar district, West Sumatra. Siriah Gadang is one of the important elements of equipment in the presentation of this Galombang dance. To achieve this goal, qualitative research was used, through interviews and observations using video recordings. The results showed that the uniqueness of Siriah Gadang was found in a reconstruction of the Galombang dance in the Pariangan village. Siriah Gadang is a dance element that does not exist in other Galombang dances in West Sumatra, so it is a characteristic of this dance.

Corresponding Author:

Afifah Asriati

afifahasriati@fbs.unp.ac.id

Published: 2 June 2021

Publishing services provided by

Knowledge E

(c) Afifah Asriati et al. This article is distributed under the terms of the Creative Commons

Attribution License, which permits unrestricted use and redistribution provided that the original author and source are credited.

Selection and Peer-review under the responsibility of the ICADECS Conference Committee.

\section{G OPEN ACCESS}

\section{Introduction}

In Minangkabau, there are several dances that exist and almost every village has that dance, one of which is the Galombang dance [1]. Galombang dance is a dance that is performed for welcoming guests, and never performed other than for that event. Traditionally, this dance was danced by men and never danced by women. However, with the development of the times, besides the traditional Galombang dance, various forms of Galombang dance that have been created have developed. One of the most prominent things that he creates is being danced by women [2].

Based on the above phenomena, at least, there are three views about the current Galombang dance, especially its relation to Minangkabau cultural values, namely; first, that this dance has been uprooted from the cultural values of the Minangkabau traditional dance;second, in this dance there has been acculturation; and third, among the elements there are those that still survive but have begun to fade.

The concept of the ideal Minangkabau dance, when viewed from the aspect of dancers who are ideally male, the movements are silat movements and the costumes are costumes commonly used in silat [3]. Meanwhile, if we look at the current situation, 
the Galombang dance shows a phenomenon that is far from its ideal value; first, a) predominantly danced by women in Minangkabau women's clothing [4]; [2], b) not thick in silat motion. As for the second phenomenon, it can be seen that the dancers have shifted to be joined by men and women where men do silat movements and women move siganjue lalai. When viewed from the clothes, it can be seen that men wear silat, women are Minangkabau traditional clothes [4]. While the third view can be found that the dancers mix male and female with silat movements [5]. The last thing that still survives even though it has faded away is the male dancer with silat movements, but the movements displayed are no longer thick in silat movements or are no longer in accordance with the original. Generally, this wave dance uses carano as equipment to wait for guests.

The unique and interesting thing about this Galombang dance in Pariangan is the Siriah Gadang in its presentation, which only exists in this village. Since previously they did not use carano as a place for betel that is served to guests, they used Siriah Gadang. This is what characterizes him [6]. Siriah Gadang is always used in conjunction with the Galombang dance in every batagak pangulu and pacu jawi event.

Based on the above phenomena, it is necessary to reconstruct the use of Siriah Gadang in the presentation of the Galombang dance. Reconstruction is carried out from past data to be seen again in the present. This data is an element of the Galombang dance performance. Which is very unique. As far as what the researchers got and also based on interviews with resource persons in the Pariangan nagari, the Galombang dance equipment like the one in Pariangan does not exist anywhere else. By carrying out this reconstruction, our efforts will become more concrete to preserve cultural objects that have not been used anymore.

On the other hand, Nagari Pariangan is a tourist area, which is one of the most beautiful villages in the world. With this nickname, of course Pariangan has become a tourist destination that is glimpsed by domestic and foreign tourists. As we know, especially foreign tourists, they want to see the unique and original culture that exists in the places they visit. For this reason, a study on the use of Siriah Gadang as an element of the Galombang dance in Pariangan village is needed. Thus this article can inspire tourists, how to use this Siriah Gadang element in the Galombang dance in Pariangan, West Sumatra.

Minangkabau traditional dance must be in accordance with the philosophy and cultural values of the Minangkabau. Because dance and music must be considered in the context of the society in which they belong [7], and what needs to be saved quickly is the cultural wealth that contains high aesthetic, ethical, technical and spiritual values 
[8]. In fact, one of the benefits of reconstructing this dance is that its authenticity is found with elements that have been forgotten so far, by involving elements that are authentic from what ever existed, but at present they do not or almost do not exist anymore [9] is absolutely necessary. While the Minangkabau people make nature not only a place where they are born, live, develop and die, but have a philosophical meaning. So that nature becomes the philosophy of life of the Minangkabau people which is revealed in the Alam Takambang Jadi Guru - Nature evolves to become Guru [10]. After Islam entered Minangkabau, customs were strengthened by the religion of Adaik Basandi Syarak, Syarak Basandi Kitabullah - Adat with syarak jointed, syarak with Kitabulllah jointed [11]. Likewise with Dance in Minangkabau.

\section{Method}

This research uses a qualitative approach. Qualitative methods are used to collect data on the reconstruction of the Galombang dance. The subject of this research is the Galombang dance in the Pariangan village. Data collection techniques were carried out by observation, interviews, FGD, and documentation with video recordings. The validity of the data was obtained through triangulation of sources and triangulation of techniques. Data analysis using Miles and Haberman's model.

\section{Results and Discussion}

The Pariangan village community, especially Jorong Guguak, belong to an art-loving society. The living habits that cultivate this art become a traditional culture that continues in the life of the people of Jorong Guguak Nagari Pariangan Tanah Datar. There are several arts that are still surviving, including Saluang, Selawat Dulang, Randai, Piring dance, Batu Barajuik dance, and Galombang dance [12].

\subsection{History of Siriah Gadang}

Based on the results of interviews with several informants in Pariangan, it is not known when the Siriah Gadang was created. What is clear is that they said that ever since they knew that Siriah Gadang was already there and used in this village. However, there is one person who estimates that it has existed since the Hindu era, since the three generations above him [13]. At that time there was no carano as used today. That's how the ancient people had the initiative to make something, especially the Siriah 
Gadang which was used by the community from generation to generation. They carry out deliberation and consensus on how and where to put this betel. So, thanks to the grace of Allah, the Siriah Gadang form is created as if it were the carano used today [13].

Siriah Gadang is used at certain events, not just on any occasion. The events that may use Siriah Gadang are community activities called alek nagari (village parties). Alek nagari what is meant by the first is mamancang alek di nagari (party in the nagari / village), the second is mamancang alek managakan pangulu (party for the appointment of a new ruler). So it's not just any party, and it's not for a wedding party either. If there is a baralek pangulu and alek pacu jawi anak nagari party (a cow race for the village / village community) then Siriah Gadang is used [13].

\subsection{The Process of Making Siriah Gadang}

The process of making Siriah Gadang starts from; First, meet a dance master and someone who can do Siriah Gadang making. Second, preparing the ingredients for making Siriah Gadang in the form of bamboo, small wood, paper, limau gadang (large oranges like grapefruit), complete betel (betel leaf, sadah, gambier, areca nut, tobacco). Third, the process of making Siriah Gadang houses. Make 5 stakes from sariak type bamboo with the size of 4 posts measuring $60 \mathrm{~cm}$ in length and $150 \mathrm{~cm}$ in the middle. Each post is connected by a small stick. If it used to be according to the informants [14] all use round bamboo and blades (bamboo that has been split into small pieces) without using nails. At the top, the posts on the edge and the middle are connected by small logs and are slightly elevated like the roof of a house. After that, each of the walls and roofs of the houses were covered with cardboard, then decorated with carvings. Originally, the roof used to be made of areca nut and the walls used kulik upiah (betel nut).

Fourth, placing the limau gadang, sirih, areca nut, gambier, tobacco, the red and white flag and the ninik mamak flag on the Siriah Gadang houses. Then, the limau gadang which has been perforated in the middle is inserted into the bamboo poles that are in the middle to the limit of the roof. Limau gadang is used to put the betel. This limes consists of three stratified pieces. Then provided 15 bunches of betel, each of which consists of 5-7 pieces of fresh betel leaves. The betel leaves are arranged together, then folded from the middle bone of the betel so that the edges of the betel leaf meet. In ancient times, the limau gadang was split into a plate like a plate. After that the tied betel is compiled. At the lower level are 7 bunches of betel, in the middle 5 bunches of 
betel, and in the third level 3 bunches of betel over once. Finally, the areca nut, the ninik mamak flag, and the white flag are also installed on the limau gadang. Fifth, in every corner of the Siriah Gadang houses there are hanged ship-shaped decorations which they say resemble the ancestral ships of the Minangkabau people. This ship decoration was inspired based on the history of the origin of the Minangkabau people.

On the walls of the Siriah Gadang houses, various carvings are made on each side which they term baukie bamego-mego (carved boasting). The motives found on the Siriah Gadang wall are ancient or old motifs. The motifs in Siriah Gadang are based on the motifs of the rumah gadang carvings. The names of the motifs are like itiak pulang patang, aka cino, kalalawa bagayuik, kaluang. These motifs were carved on top of kulik upiah (areca petals) [14].

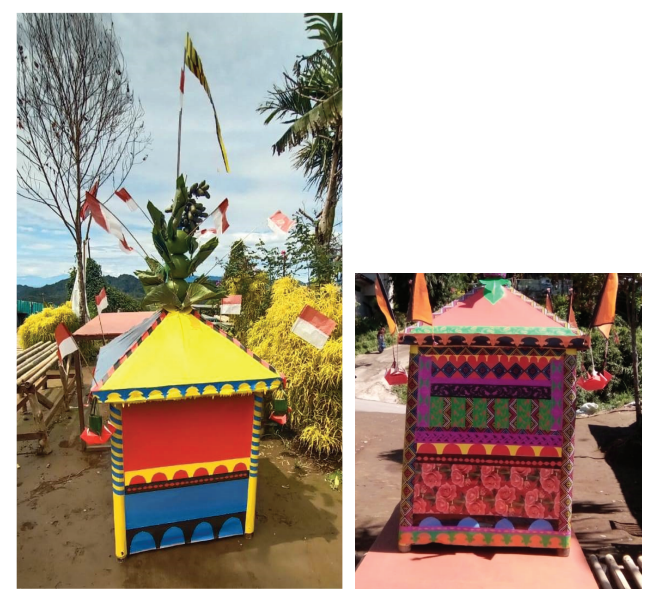

Figure 1: Siriah Gadang (Documentation: Afifah Asriati, 5 September 2020)

\subsection{The use of Siriah Gadang in the presentation of the Galom- bang dance in welcoming guests}

Furthermore, the Siriah Gadang that has been made earlier is used in the presentation of the Galombang dance in welcoming guests. The structure for the presentation of the use of Siriah Gadang in the Galombang dance can be described as follows: a) Guests are in front of the Galombang dancers, b) The dancers stand in line backwards to prepare to start the dance movement, and Siriah Gadang is placed in the middle of the line of dancers in left and right. c) Dancers perform the first part of the Galombang dance. Starting from the gesture of greeting, until the movement of racing (fighting motion). After that, the dancers face to face in the middle then take a step back so that guests who enter the Galombang dancer line can enter freely. d) Guests are welcome to the Siriah Gadang and stand in front of the Siriah Gadang. e) Pasambahan words 
from tuo tari, as a welcome greeting to a respected guest. In the last sentence, it is conveyed that guests are welcome to take betel which is located above the Siriah Gadang houses. f) Guests take betel, g) Dancers do the second part. In the last motion the dancer performs a motion that describes the guests being welcome to the venue, i) Guests go to the venue while being accompanied by traditional talempong pacik music to accompany guests in a procession to the venue, j) the dancer takes the Sirih Gadang and brings Siriah Gadang to the venue, then Siriah Gadang is placed in front of the guests who sit in the space provided.

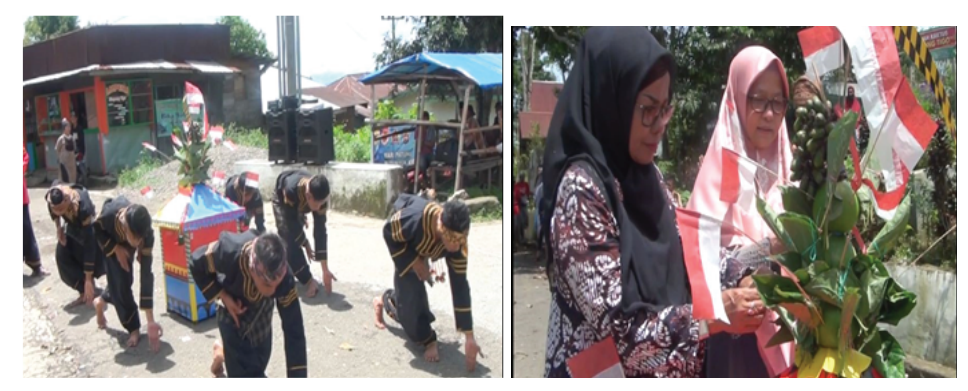

Figure 2: Siriah Gadang is placed in the middle and dancers move beside and guests take betel over the Siriah Gadang houses (Documentation: Afifah Asriati, 5 September 2020)

Based on the findings of the use of Siriah Gadang in the reconstruction of the Galombang dance that has been described above, the results can be used in every guest welcoming event both in the batagak pelulu and pacu jawi events. And it could be to welcome guests apart from the two events above. With the re-emergence of the use of Siriah Gadang in the reconstruction of this Galombang dance, of course this is an effort to preserve the arts, especially the Siriah Gadang which has not been used for a long time. The reconstruction that is useful for preserving this culture has also been carried out at the Kasunanan Surakarta Hadiningrat Palace. The reconstruction was carried out based on the authority of Gusti Kanjeng Ratu Wandansari [15]. Therefore, efforts to maintain and preserve art in order to keep growing, one of which is by carrying out reconstruction activities [16].

The Minangkabau people agree that if there are guests who come to their area like a referee, then their arrival is greeted with a game of Galombang. [17]. The dance ceremony is closed with serving a piece of betel to the guests [17]. A carano carrier holding a carano filled with betel nut approaches the guest to pick up the group of guests [18] which is then taken to the venue. Serving betel to guests is to say welcome. The mancabiak (tearing) betel that was served by the host was an expression of gratitude for the host's welcome. Eating betel or mancabiak betel is a symbol of harmonious communication in a traditional ceremony in Minangkabau [19]. Siriah 
Gadang is also used as an ornamental ornament in Minangkabau. Siriah Gadang is an expression of the attitude of the Minangkabau people in honoring guests [19].

\section{Conclusions and Suggestions}

It has been found that the use of the Siriah Gadang element in the reconstruction of the Galombang dance is based on reflections from various credible sources. In its use it functions as a tribute to guests. Not carano as can be seen now. This is one of the uniqueness of the Galombang dance in this tuo village.

It is hoped that the people of Jorong Guguak Nagari Pariangan can maintain the results of this reconstruction. and it is hoped that the village government will perform this dance if there are guests who come to the Pariangan village especially to the Guguak jorong.

\section{References}

[1] Sedyawati, E. (1981). Pertumbuhan seni pertunjukan. Sinar Harapan.

[2] Indrayuda., Ardipal. (2017). Women domination in the Galombang dance: Between the customary idealism and the market use. Harmonia: Journal of Arts Research and Education, 17(2), 153-162.

[3] Asriati, A., Kosasih, A., \& Desfiarni. (2019). Silat as the source and identity of the Minangkabau ethnic dance. Harmonia: Journal of Arts Research and Education, 19(2), 71-83.

[4] Adnan, N. (2013). Tari Galombang di Minangkabau menuju industri pariwisata. Journal of Urban Society's Art, 13(2) 37-49.

[5] Utama, I. (2017). Tari Minangkabau: Dari Pancak dan Pamenan ke tari Persembahan. University Malaya.

[6] Asriati, A. (2018, September 28). Interviewee, Observasi [Interview].

[7] Royce, A. P. (2007). Antropologi tari (F. X. Widaryanto, Trans). Sunan Ambu Press.

[8] Sedyawati, E. (2014). Kebudayaan di nusantara: Dari keris, tor-tor sampai industri budaya. Komunitas Bambu.

[9] Djelantik. (1999). Seni pertunjukan di Era Globalisasi. Gadjah Mada University Press.

[10] Amir, M. S. (1999). Adat Minangkabau: Pola dan tujuan hidup orang Minang. PT Mutiara Sumber Widya. 
[11] Navis, A. (1984). Alam terkembang jadi guru: Adat dan kebudayaan Minangkabau. PT Grafiti.

[12] Maizar. (2020, August 29). Interviewee, Wawancara [Interview].

[13] Sani, M. (2020, August 29). Interviewee, Wawancara [Interview].

[14] Sani, M. (2020, September 5). Interviewee, Wawancara [Interview].

[15] Herawati, K. P., \& Prihatinia, N. S. (2018). Rekonstruksi tari Bedhaya Endhol-endhol di Keraton Kasunanan Surakarta Hadiningrat. Panggung, 28(2), pp. 231-243.

[16] Susanti, D. (2018, October 11). Rekonstruksi Tari Zapin Duo Di Kelurahan Teluk Dalam Kecamatan Kuala Kampar Kabupaten Pelalawan Propinsi Riau [Seminar paper]. Seminar Antar Bangsa: Seni Budaya dan Desain - STANSA, Malang, Indonesia. http://seminarsedesa.um.ac.id/wp-content/uploads/2018/12/6-UREKONSTRUKSI-TARI-ZAPIN-DUO.pdf

[17] Nerosti. (2019). Nilai-Nilai kearifan lokal melalui tari Galombang gaya sasaran: Studi sasaran sebagai sarana pendidikan kultural. Dance \& Theatre Review, 2(1), 35-41.

[18] Soedarsono. (2002). Seni pertunjukan Indonesia: Di Era Globalisasi (3 ${ }^{\text {rd }}$ d.). Gadjah Mada University Press.

[19] Syafwandi, \& Zubaidah. (2018). Makna filosofi ornamen hias tradisional Minangkabau masihkah relevan dengan pola kehidupan masyarakat sekarang, ranah seni. Jurnal Seni dan Desain, 12(1), 489-498. 